\title{
The Effect of Destination Image, Amenities and Prices on Tourists' Satisfaction: A Study of Visitors of Jatim Park 1, Batu
}

\author{
Denis Twi Febinanda ${ }^{*}$, Peter Remy Yosy Pasla and Uki Yonda Asepta \\ ${ }^{1}$ University of Ma Chung Malang
}

(Received October 23, 2018; Accepted November 26, 2018; Published December 27, 2018)

\begin{abstract}
The purpose of this study is to analyze the influence of the destination image, amenities, and prices on the satisfaction of visitors to Jatim Park 1 Batu. The population of this study was visitors to Jatim Park 1 Batu at the time of this study, in April 2018. The sample size used was 100 respondents with the criteria that they had visited Jatim Park 1 and were 20 years old or more. The data were obtained through questionnaires, where tourists accessed via the Google forms application. Data analysis used was a descriptive approach and multiple linear regression statistics. The results show that tourist satisfaction was significantly influenced by prices variable, while the destination image and amenity did not show influence. Thus, Jatim Park 1 manager needs to improve promotion, product development, and quality services to provide a destination image and comfort for tourists.
\end{abstract}

Keywords: destination image, Batu, Jatim Park, tourist satisfaction

JEL Classification: D22, M31, Z30

\section{INTRODUCTION}

Batu City has adequate facilities to encourage tourism activities, supporting services and accessibility to various tourist attractions (BPS Kota Batu, 2017). Batu has a variety of tourism objects, such as natural tourism, cultural tourism and creative tourism, reaching around 25 tourist destinations. Road infrastructure in good condition reaches $70 \%$, supported by adequate public transportation modes.

Batu Local Government continues to develop various facilities in improving amenities that are able to provide an increase of city budget. The performance of the tourism sector based on data of the Batu Tourism and Culture Office (Disparbud) experienced an increase of 367 thousand tourists in 2016 with the total 2551 thousand tourists visit. This figure increased around $14.36 \%$ compared to 2015 (BPS Kota Batu, 2017). During holiday, for example at the end of the year, it becomes a

\footnotetext{
* Corresponding author email: denistwifebinanda@gmail.com, ISSN 2615-6075 online; ISSN 2615-6946 print @UWG Press, 2018

OJS http://publishing-widyagama.ac.id/ejournalv2/index.php/jsed/
}

special attraction for tourists to visit Batu. Batu City become crowded and jammed by the arrival of tourists from various regions. They enjoy the end of the year by traveling in various tourist destinations in the city of Batu.

Tourism development advancement can also increase income, employment and foreign exchange in the region. The way to attract tourists to revisit and or recommend a destination to others is very complicated mechanism for the progress of developing a destination. The image of a destination influences the desire of tourists to visit. Chen \& Tsai (2007) suggest that a destination image plays two important roles in behaviors: (1) to influence the destination choice in decisionmaking process and (2) to prepare the afterdecision making behaviors including participation (on-site experience), evaluation (satisfaction) and future behavioral intentions (intention to revisit and willingness to recommend).

The destination images make it easier for tourists to make decisions about their journey and determine whether their travel experience will be very satisfying (Qu, Kim, \& Im, 2011). From the perspective of the tourist consumption process, 
tourist behavior can be divided into three stages: before the visit, during the visit and after the visit. More specifically, tourist behavior is a complete term that includes taking pre-visit decision behaviors, evaluating experience in tourist attractions and post-visit behavior (Chen \& Tsai, 2007).

Table 1. The Number of Visitor per Month in Batu City

\begin{tabular}{lc}
\hline Month & Visitors \\
\hline & thousand people \\
January & 265.1 \\
February & 166.0 \\
March & 198.2 \\
April & 205.7 \\
May & 315.0 \\
June & 135.2 \\
July & 369.4 \\
August & 173.6 \\
September & 181.6 \\
October & 204.6 \\
November & 196.7 \\
December & 506.6 \\
\hline
\end{tabular}

Source: (BPS Kota Batu, 2017)

Beside the destination image, facilities also affect tourists to come to a tourist attraction. According to Spillane (1994), facilities are infrastructure that support the operation of tourism objects to accommodate all the tourists needs. It is not directly encourage growth but develop at the same time or after developing attractions.

One of the tourist destinations in Batu is Jatim Park 1. Jatim Park 1 provides the entertainment venues with the theme of entertainment and education. Jatim Park 1 which was established on March 2, 2002 has grown to more than 50 rides. Jatim Park 1 is one of the most developing tourism place in Batu. To expand it, the owner develops Jatim Park 2 and Jatim Park 3 in other areas in Batu City. The target of the development is to add 3 rides every year. The development of Jatim Park tourism rides is expected to continue to attract tourists to visit Batu.

Nowadays, Jatim Park 1, the tourist park, has a total of 60 rides, outbound, parks, and educational spots. Tourists are considered important to assess a destination because tourists are buyers or connoisseurs of services offered by tourism destinations. Tourists evaluate a tourism destination through its beliefs and perceptions, which can then be referred to as the destination image.
From several tourist attractions in Kota Batu, Kusuma Agro and Selecta in 2016 significantly gained an increase in the number of visitors compared years before. On the other side, Cangar, Jatim Park 1 and BNS decreased in the number of visitors in those periods. As an agricultural-based tourist attraction, Kusuma Agro still has a special attraction for tourists visiting Batu. The increase in the number of visitors in Selecta and Kusuma Agro in 2016 was at $12.2 \%$ and $72.7 \%$ compared one year before (BPS Kota Batu, 2017).

Table 2. The Number of Visitors in Selected Tourism Site in Batu City

\begin{tabular}{|c|c|c|c|c|}
\hline Tourism sites & 2013 & 2014 & 2015 & 2016 \\
\hline & \multicolumn{4}{|c|}{...............thousand people ............. } \\
\hline Jatim Park (1\&2) & 345.6 & 329.2 & 106.3 & 159.6 \\
\hline Selecta & 756.2 & 702.7 & 788.2 & 1077.1 \\
\hline Kusuma Agro & 15.4 & 163.9 & 283.1 & 303.7 \\
\hline Cangar & 232.2 & 255.9 & 211.5 & 229.6 \\
\hline BNS & 310.2 & 271.9 & 248.7 & 254.2 \\
\hline
\end{tabular}

Source: (BPS Kota Batu, 2017)

Table 2 shows that the visitors number of Jatim Park 1 have decreased during 2013-2016 periods. The visitor number decrease from 345.6 thousand become 159.6 thousand tourists. This is also experienced by Cangar and BNS with the number of decrease of 1 and $18 \%$, respectively. The development of new tourist attractions cause a lot of alternatives for tourists in visiting Batu, so there are many tourist attractions that show a significant decrease in the number of visitors.

Beside the image of destinations and amenities, a tourist attraction is also influenced by prices. In marketing activities, there are four elements that must be done by each business entity, including product, price, place, and promotion. The researcher will only discuss prices and promotions. This is expected to know how the influence of both prices and promotions on tourist satisfaction. According to Kotler (2008), price is the sum of all the values given by a customer to the benefit with owning or using a product or service.

This study is to explore tourists' opinions who went to Jatim Park 1 in terms of the destinations image, amenity, and prices regarding to tourist satisfaction. This is expected that tourism development in Jatim Park 1 can manage in harmony as tourists' need, so, the tourists can obtain satisfaction and create a possibility for 
tourists to revisit to Jatim Park 1 as one of the tourism destinations that deserve to be visited. In addition, this study is expected to know what factors need to be sustained and improved from tourism facilities in Jatim Park 1 to support the better quality of tourism destinations.

In short, this research aims to analyze the influence of destination images, amenity, and prices on tourist satisfaction in Jatim Park 1, Batu.

\section{RESEARCH METHOD}

The research approach used was a quantitative approach. Quantitative research is a research method based on the philosophy of positivism, used to examine certain populations or samples, and fulfill scientific principles; concrete or empirical, objective, measurable, rational, and systematic. This method is also called the discovery method because it can find and develop a new phenomenon, science and technology. This method uses numerical data analyzed using statistics (Sugiyono, 2016).

The population in this study were visitors to the Jatim Park 1, Batu. The study was conducted on April 2018. The population size in this study was very large and could not be surely known. They were people who had visited to Jatim Park. The sample size is calculated by the following formula (Widiyanto, 2008):

$$
\begin{aligned}
& n=\frac{Z^{2}}{4(M o E)^{2}} \\
& n=\frac{(1,96)^{2}}{4(0,10)^{2}} \\
& n=96,04=97
\end{aligned}
$$

From the calculation of the formula above, it can be obtained that the sample size studied is 97 , or rounded to 100 respondents. The sampling method uses purposive sampling, in which the samples are technique of determining the sample is with certain considerations or criteria (Sugiyono, 2016). The criteria are respondents who have visited Jatim Park 1 and those are in the age of $\geq$ 20 years.

The steps taken in the sampling technique are online questionnaires created through the google forms application. The form was sent to people on the chat line and was got as many as 100 participants (respondents). In measuring respondents' answers about the image of destinations, tourist facilities, prices and tourist satisfaction, a likert scale was used.

In this study, the variables analyzed are as follows:

a. Independent Variables. According to (Sugiyono, 2016), independent variables are those that influence or cause changes or the emergence of the dependent variable (bound). The independent variables in this study are:

1) Destination Image (X1). According to Engel, Blackwell, \& Kollat (1978), an image is the way in which a product or brand is defined in the shopper's mind, in part by its functional quality and partly by its psychological attributes. In this case, the destination image is the overall evaluation or perception of the tourist towards the tourist attraction of Jatim Park 1 Batu. The indicator of destination image used in this study refers to the opinion of Qu et al. (2011), they are: a) Cognitive image (X1.1), b) Unique image (X1.2), c) Affective image (X.1.3)

2) Amenity (X2). Amenity are supporting facilities that can create a sense of fun followed by the ease and fulfillment of the tourists needs in enjoying the tourist products offered. In this case the tourism facility (amenity) is very necessary as long as visitors are in Jatim Park 1 Batu. The amenities indicators used in this study were based on Peter Mason theory (Poerwanto, 2004) that tourism product components include three main indicators: a) accommodation (X2.1), b) restaurant $(\mathrm{X} 2.2)$, and $\mathrm{c}$ ) basic (X2.3)

3) Price (X3). According to Kotler (2008) the price is the sum of all values exchanged by consumers for the benefits of owning or using the product or service. The price indicator used in this study refers to the opinion of (Stanton, Etzel, \& Walker, 1991): a) affordability (X3.1), b) the compatibility with product quality (X3.2), c) competitiveness $(\mathrm{X} 3.3)$, d) suitability with benefits (X3.4),

b. Dependent Variables. Dependent variables are those that are influenced or which are due to the existence of independent variables (Sugiyono, 
2016). The dependent variable in this study is tourist satisfaction ( $Y$ ) that is a feeling of disappointment or pleasure felt by someone, which arises due to comparing perceived performance of the product (or outcome) to the expectations of buyers (Kotler \& Keller, 2012). In this case, the satisfaction of tourists is the treatment and service perceived by tourists towards the Jatim Park 1 Batu. The tourist satisfaction indicators used in this study was the service quality theory of ZeithamlParasuraman-Berry: a) physical facilities (tangibles) - $(Y 1.1), b)$ reliability - $(Y 1.2), c)$ responsivess $(\mathrm{Y} 1.3), \mathrm{d})$ assurance - (Y1.4), e) emphaty - (Y1.5).

The data analysis technique used is regression model, with the formula:

$$
\mathrm{Y}=\mathrm{a}+\beta_{1} \mathrm{X}_{1}+\beta_{2} \mathrm{X}_{2}+\beta_{3} \mathrm{X}_{3}+\mathrm{e}
$$

In which $\mathrm{Y}$ : tourist satisfaction variables, $\mathrm{X} 1=$ destination image variables, X2: amenity variables, $\mathrm{X} 3$ : price variable, a: constants, $\beta_{1}-\beta_{3}$ : regression coefficient, e: error

\section{RESULT AND DISCUSSION}

\section{Characteristic of Respondent}

The characteristics of the research respondent are presented in Table 3. The respondent's characteristics can explain the portrait of the response to the visitor satisfaction obtained with tourist destinations. Based on the gender, male respondents is 86 people ( $86 \%$ ) and the remaining women is 14 people (14\%). Based on the age, $86 \%$ respondents of Jatim Park 1 is between 20 and 29 years, $3.0 \%$ is in the age of 30 to 39 , and $11 \%$ is in the age of 40 to 49 years old.

The education characteristics of respondents consist of $37 \%$ graduated from undergraduate (S1), $37 \%$ graduated from Diploma (D3), 57\% graduated from senior high school and $2.0 \%$ graduated from junior high school.

Based on the nature of the visit, $10 \%$ of respondents stated that it was the first time to visit to Jatim Park 1. The rest, that is $90 \%$ of respondents went to the site many times because they accompany friends, family or other interests.

Based on the companian visit, $36 \%$ of respondents went there accompanied by family, $58 \%$ visited with friends, and $6 \%$ went by themselves. Meanwhile, there was no respondent found using the agency's travel services.

Table 3. The Characteristics of Respondent

\begin{tabular}{lc}
\hline Variable & Proportion \\
\hline & $\%$ \\
Age & 0 \\
- less than 20 years & 86 \\
- 20 - 29 years & 3 \\
- 30 - 39 years & 11 \\
- 40 - 49 years & 0 \\
- Above 50 years & \\
Gender & 86 \\
- Male & 14 \\
- Female & \\
Education & 31 \\
- Undergraduate or above & 4 \\
- Diploma & 57 \\
- Senior High School & 2 \\
- Yunior High School & 0 \\
- Elementary School & \\
Frequency of visit & 10 \\
- First visit & 90 \\
- Revisit & \\
Companion of visit & 36 \\
- Family & 58 \\
- Friend & 0 \\
- Travel service & 6 \\
- Alone & \\
\hline The Number of respondent are 100 participants & \\
\end{tabular}

According to Chang, Backman, \& Huang (2014), the tendency of revisit to tourist sites is determined by products and tourism services based on the creative industries including unique and authentic traditional culture and art. Business managers or operators need to explore the experiences of tourists, and develop services to meet the needs and desires of tourists. They need to pay more attention to what travelers' experience when they visit creative tourist attractions.

\section{Tourist Satisfaction}

The results of the regression analysis on the visitor satisfaction are presented in Table 4. In general, the statistical analysis show an estimate variables that significantly influence visitors' satisfaction. The results of multiple linear regression analysis is expressed through equation as follows:

$$
Y=1.070+0.040 X 1+0.155 X 2+0.317 X 3+e
$$

Table 4 shows statistic $t$ of destination image variable is not significant, with $p$ value 0.674 . This means that the destination image has no significant effect on tourist satisfaction. 
Table 4. The Estimate Variable of Tourist Satisfaction

\begin{tabular}{lccc}
\hline Independent Variable & $B$ & $t$ & p value \\
\hline Constant & 1.070 & 3.512 & 0.001 \\
Destination Image & 0.040 & 0.422 & 0.674 \\
Amenity & 0.155 & 1.530 & 0.129 \\
Price & 0.317 & 3.756 & 0.000 \\
\hline
\end{tabular}

The result of this research is not in line with previous studies such as (Kristanti \& Farida, 2016), (Dananjaya, Kencana, \& Sukarsa, 2017), (Hanif, Kusumawati, \& Kholid Mawardi, 2016), and (Alfitriani, 2015). They stated that destination image has a significant effect on Tourist Satisfaction.

These results indicate that destination image of Jatim Park 1 has experienced a change or decline. This is a result of the development of other tourism objects in Batu. Currently, other tourism objects have been developed such as: BNS (Batu Night Spectacular), Eco Green Park, Museum Angkut, Museum Tubuh, Predator Fun Park and others. Previously, Jatim Park 1, which became the main tourist icon in Batu, gradually decrease in image because tourists see other attractions besides Jatim Park 1 in Batu.

Given descriptive statistics, the destination image of Jatim Park 1 show score range in the interval 4.21-5.00 with the average score at the point of 4.26. This number falls into very high criteria. This means that respondents strongly agree that Jatim Park 1 show the Destination Image with its beautiful environment. The name of Jatim Park 1 is easy to remember. The Jatim Park 1 has also many rides as desired by the visitors. Jatim Park 1 is a famous and favorite tourist attraction in East Java.

Meanwhile, amenity variable have no significant effect on tourist satisfaction. This variable shows $t$ statistic of 1.530 and $p$ value of 0.129 . This results are not in accordance with the previous studies (Kristanti \& Farida, 2016), (Ali \& Khuzaini, 2017), and (Suchaina, 2014).

Amenity related to the facilities provided at tourism site. Facilities that are inadequate in terms of quality or quantity create discomfort for tourist. The condition of tourist facilities in Jatim Park 1 supposedly did not support tourism amenity. Tourists have preferences and compare facilities at other tourist destinations. Tourists possibly find satisfaction with facilities at other tourism site.

The descriptive analysis of amenity variable shows the score range in the interval of 3.41- 4.20 and the average point of 3.88. This number is at the high criteria. This means that respondents agree that the facilities at Jatim Park 1 are affordable and satisfying. In general, services and facilities in and around Jatim Park 1 can be accessed easily. Lodging is available in many choices, not far away, at affordable prices. Restaurants or stalls are available in various kinds of food and beverage menus with reasonable prices. Other facilities are available in adequate conditions, including parking areas, prayer rooms, souvenir shops or toilets around the Jatim Park 1 area.

Table 4 shows statistic $t$ of price variable is significant, with $B$ coefficient 0.317 and $p$ value 0.674. This means that the price has significant effect on tourist satisfaction. The results of the study are in accordance with the previous studies (Wulandari \& Wahyuati, 2017), where they state that price has a significant effect on tourist satisfaction.

The descriptive analysis of price variable shows the score range in the interval of 3.41- 4.20 and the average point of 3.81. This number is at high criteria. This means that the respondents agree that the entrance ticket to the Jatim Park 1 is affordable. The ticket price is in accordance with the product offered, cheaper, and satisfied with the facilities provided.

In general, the results of the study have the following implications:

1. The management of Jatim Park 1 continues to develop promotions, compete with other destinations to attract tourists. The image will also be built through promotions by using various promotional media, and adjusting the tourists' wants and needs.

2. The management of Jatim Park 1 continues to develop facilities, accommodations and services that are desired and affordable by tourists. Tourism products and services are developed by finding uniqueness (Qu et al., 2011) with education that invites tourists to be involved in learning or education. Good and friendly service 
is given to meet the needs and satisfaction of tourists (Wulandari \& Wahyuati, 2017)

3. The management of Jatim Park 1 continuously develops a competitive price system followed by service quality and tourist involvement in a comfortable atmosphere.

\section{CONCLUSION AND SUGGESTION}

Tourist respondents of Jatim Park 1 were dominated by ages of 20 and 29 years, namely $86 \%$. A $10 \%$ of respondents stated that it was the first visit to Jawa Timur Park 1, while the other $90 \%$ came several times. A $36 \%$ of respondents went accompanied by family, and $58 \%$ visited with their friends.

The results of the regression analysis show that tourist satisfaction is significantly influenced by price, with $\beta$ coefficient 0.317 and $p$ value 0.674 . Meanwhile, destination image and amenity variables do not show significant influence. The research implies that the management of Jatim Park 1 continues to develop promotions, compete with other tourism site to improve the destination image. The management of Jatim Park 1 needs to create a competitive price system, followed by product development, service quality and tourist involvement in a comfortable atmosphere.

\section{REFERENCES}

Alfitriani. (2015). Pengaruh Citra Destinasi Terhadap Kualitas, Nilai Persepsi, Kepuasan dan Minat Berprilaku: Kasus Kunjungan Wisatawan di Kota Palembang. Menara Ekonomi, 1(2), 1-8. Retrieved from https://media.neliti.com/media/publications/107 418-ID-pengaruh-citra-destinasi-fasilitaswisat.pdf

Ali, M. T. R., \& Khuzaini. (2017). Pengaruh Harga, Kualitas Produk, Lokasi, dan Fasilitas Terhadap Keputusan Pembelian Rumah. Ilmu Dan Riset Manajemen, 6(9), 1-20. https://tixpdf.com/pengaruh-harga-kualitasproduk-lokasi-dan-fasilitas-terhadap.html

BPS Kota Batu. (2017). Statistik Daerah Kota Batu. Batu: BPS Kota Batu.

Chang, L. L., Backman, K. F., \& Huang, Y. C. (2014). Creative tourism: a preliminary examination of creative tourists' motivation, experience, perceived value and revisit intention. International Journal of Culture, Tourism, and Hospitality Research, 8(4), 401-
419. https://doi.org/10.1108/IJCTHR-04-2014$\underline{0032}$

Chen, C. F., \& Tsai, D. C. (2007). How destination image and evaluative factors affect behavioral intentions? Tourism Management, 28(4), 11151122.

https://doi.org/10.1016/i.tourman.2006.07.007

Dananjaya, I., Kencana, I., \& Sukarsa, I. (2017). Analisis Pengaruh Citra Destinasi dan Motif Berwisata Terhadap Tingkat Kepuasan Wisatawan Lanjut Usia. E-Jurnal Matematika, 6(2), 131-136. https://doi.org/10.24843/MTK.2017.v06.i02.p15 7

Engel, J. F., Blackwell, R. D., \& Kollat, D. T. (1978). Consumer Behavior (3rd ed.). Dryden Press. Retrieved from https://books.google.co.id/books?id=LXyOAAAA CAAJ

Hanif, A., Kusumawati, A., \& Kholid Mawardi, M. (2016). Pengaruh Citra Destinasi Terhadap Kepuasan Wisatawan Serta Dampaknya Terhadap Loyalitas Wisatawan (Studi pada Wisatawan Nusantara yang Berkunjung ke Kota Batu). Jurnal Administrasi Bisnis (JAB)|Vol, 38(1), 44-52. Retrieved from http://administrasibisnis.studentjournal.ub.ac.id index.php/jab/article/download/1480/1859

Kotler, P. (2008). Manajemen Pemasaran. Manajemen Pemasaran (Milenium). Jakarta: Prenhallindo.

Kotler, P., \& Keller, K. L. (2012). Marketing Management (14th ed.). Pearson. Retrieved from

https://books.google.co.id/books?id=eMZRYgEA CAA]

Kristanti, L. T., \& Farida, N. (2016). Pengaruh Citra Destinasi dan Fasilitas Wisata terhadap Niat Berperilaku Melalui Kepuasan Sebagai Variabel Intervening (Studi pada Pengunjung Museum Kereta Api Ambarawa). Jurnal Ilmu Administrasi Bisnis, 5(3). Retrieved from https://ejournal3.undip.ac.id/index.php/jiab/arti cle/view/12144/11796

Poerwanto. (2004). Geografi Pariwisata (Diktat Kuliah). Jember: Universitas Jember.

Qu, H., Kim, L. H., \& Im, H. H. (2011). A model of destination branding: Integrating the concepts of the branding and destination image. Tourism Management, 32(3), 465-476. https://doi.org/10.1016/j.tourman.2010.03.014

Spillane, J. J. (1994). Pariwisata Indonesia: Siasat 
Ekonomi Dan Rekayasa Kebudayaan. Yogyakarta, Indonesia: Penerbit Kanisius. Retrieved

from

https://books.google.co.id/books?id=jrCAAAAA MAA]

Stanton, W. J., Etzel, M. J., \& Walker, B. J. (1991). Fundamentals of marketing (9th ed.). McGrawHill. Retrieved from https://books.google.co.id/books?id=JlcPAQAA MAA]

Suchaina. (2014). Pengaruh Kualitas Fasilitas Sarana dan Prasarana Terhadap Peningkatan Jumlah Pengunjung Wisata Danau Ranu Grati. Jurnal Psikologi, 2(2), 89-109. Retrieved from http://jurnal.yudharta.ac.id/v2/index.php/ILMU-
PSIKOLOGI/article/view/1072/938

Sugiyono. (2016). Metode Penelitian Kuantitatif Kualitatif dan R and D (23rd ed.). Alfabeta, Bandung.

Widiyanto, I. (2008). Metodologi Penelitian. Semarang: BP Undip.

Wulandari, V., \& Wahyuati, A. (2017). Pengaruh Fasilitas, Pelayanan, dan Harga Terhadap Kepuasan Wisatawan. Jurnal Ilmu Dan Riset Manajemen, 6(3), 1-20. Retrieved from https://tixpdf.com/pengaruh-fasilitaspelayanandan-harga-terhadap-kepuasanwisa.html 